\title{
Montmorillonite K10 Clay Catalyzed One Pot Synthesis of 2,4,6-Tri Substituted Pyridine under Solvent Free Condition
}

\author{
Vellayan Kannan $^{1^{*}}$, Krishnapillai Sreekumar ${ }^{2}$ \\ ${ }^{1}$ Department of Chemistry, Government College Kattappana, Kattappana, India \\ ${ }^{2}$ Department of Applied Chemistry, Cochin University of Science and Technology, Cochin, India \\ Email: "kannanpvl@gmail.com
}

Received January 11, 2013; revised February 27, 2013; accepted March 11, 2013

Copyright (C) 2013 Vellayan Kannan, Krishnapillai Sreekumar. This is an open access article distributed under the Creative Commons Attribution License, which permits unrestricted use, distribution, and reproduction in any medium, provided the original work is properly cited.

\begin{abstract}
Montmorillonite K10 catalyzed synthesis of 2,4,6 triaryl pyridine under solvent free condition is described. Montmorillonite effectively catalyzed the reaction in good to excellent yields. Using this solid catalyst, the reactions could be carried out in a short period of time with very good yield of triaryl pyridines, up to $97 \%$ under solvent free condition. This catalyst could be recycled very easily, which makes this methodology environmentally benign. The catalyst is active over three cycles.
\end{abstract}

Keywords: Clay Catalyst; Solvent Free Synthesis; Substituted Pyridine

\section{Introduction}

One-pot multicomponent coupling reactions (MCRs), where several organic moieties are coupled in one step, for carbon-carbon and carbon-heteroatom bond formation is an attractive synthetic strategy for the synthesis of small-molecule libraries with several degrees of structural diversities [1]. Multiaryl substituted pyridine derivatives are recently reported as electron transport materials [2]. The highly substituted pyridine derivatives, like 2amino-4-aryl-3,5-dicyano-6-sulfanylpyridines have significant and diverse medicinal utility. Essentially, these compounds serve as high-potency agonists for the human adenosine receptors and act as potential therapeutic agents for the treatment of Creutzfeldt-Jacob disease, Parkinson's disease, hypoxia, asthma, cancer, kidney disease and prion disease [3-5]. Due to their ח-stacking ability, some pyridines are used in supramolecular chemistry [68]. Previously, 2,4,6-triarylpyridines have been prepared by the condensation of 1,5-diketones with formamide-formic acid [9], reaction of (aroylmethylene) isoquinolinium ylide with $\alpha, \beta$-unsaturated ketones $[10,11]$, and reaction of $\mathrm{N}$-phenacylpyridinium salts with $\alpha, \beta$-unsaturated ketones in the presence of ammonium acetate

"Corresponding author.
[12]. More recently, many improved methods for preparation of 2,4,6-triaryl pyridines have been reported such as reaction of $\alpha$-ketoketene dithioacetals with methyl ketones in the presence of ammonium acetate [13], reaction of N-phosphinylethanimines with aldehydes [14], addition of lithiated $\beta$-enaminophosphonates to chalcones [15], condensation of acetophenones, benzaldehydes and $\mathrm{NH}_{4} \mathrm{OAc}$ in the presence of $\mathrm{NaOH}$ under solvent free condition [16], one pot reaction of acetophenones, benzaldehydes and $\mathrm{NH}_{4} \mathrm{OAc}$ without catalyst under microwave irradiation [17] etc. Due to the non corrosive, easy to handle, thermally robust, inexpensive and environmental friendly nature of clays have gained importance in organic synthesis as solid acid catalysts. Montmorillonite $\mathrm{K} 10$ has proved to be an efficient catalyst in promoting various organic reactions such as addition reaction [18], Knovenagal condensation [19], Aza-Diels Alder reaction [20], Esterification [21], isomerisation reaction [22] etc. However, the utility of this catalyst for the synthesis of trisubstituted pyridines under solvent free condition has not been explored before. In continuation of our efforts to explore the catalytic activity of clays for various organic transformations, a one-pot solvent free synthesis of 2,4,6trisubstituted pyridines by condensation of various aldehydes, ketones and ammonium acetate have been attempted. 


\section{Experimental Procedure}

Commercial clay K10 was purchased from Sigma-Aldrich India. The clay was activated at $200^{\circ} \mathrm{C}$ for $3 \mathrm{~h}$ before use. The reactants were purchased from Merck Ltd. India and were used as such. The products were characterized by FT-IR, NMR spectral methods and m. p. FT-IR spectra were recorded by the $\mathrm{KBr}$ pellet method on a JASCO FT-IR spectrometer in the range of 400 to $4000 \mathrm{~cm}^{-1}$. High-resolution mass spectra were obtained with a LC-MS (Q-TOFF) LC (Waters). ${ }^{1} \mathrm{H}$ NMR spectra were recorded on a Bruker $400 \mathrm{MHZ}$ instrument with tetra methyl silane (TMS) as internal standard in $\mathrm{CDCl}_{3}$.

\subsection{Synthesis of 2,4,6 Triaryl Pyridines}

A mixture of aldehyde $(1 \mathrm{mmol})$, acetophenone $(2 \mathrm{mmol})$, $1.3 \mathrm{~mol} \%\left(\mathrm{NH}_{4} \mathrm{OAc}\right)$ and activated $\mathrm{K} 10$ clay $(0.2 \mathrm{~g})$ was stirred at $120^{\circ} \mathrm{C}$. The progress of the reaction was monitored by TLC. After the completion of the reaction, hot ethanol was added to the mixture and the insoluble catalyst was filtered off. The pure product was obtained by recrystalisation from the solvent.

\subsection{Reusability of the Catalyst}

At the end of the reaction the catalyst was filtered, washed with diethyl ether, dried at $130^{\circ} \mathrm{C}$ for $1 \mathrm{~h}$, and reused. The recycled catalyst was found to be active over three cycles without appreciable loss in catalytic activity. Results are given in Table $\mathbf{1 .}$

All the products are known compounds and were characterized by comparing IR and ${ }^{1} \mathrm{H}$ NMR spectral data as well as melting points with those reported in the literature. All yields refer to that of isolated pure products.

\section{Results and Discussion}

The catalytic efficiency of K10 was evaluated for the synthesis of triaryl pyridines by a one pot condensation of aldehyde, ketone and $\mathrm{NH}_{4} \mathrm{OAc}$ under solvent free condition (Scheme 1). High yield (97\%) was obtained with benzaldehyde and acetophenone. To evaluate the scope and limitations of the methodology, reactions were carried out with various substituted benzaldehydes including both electron-donating and electron-withdrawing substituents at para position of the aromatic ring (Table 2). The results showed that there is no adverse effect of substituents, either electron-donating or electron-withdrawing, on the aromatic ring of benzaldehyde or acetophenone on the product yield. In the case of all the aldehydes, very high yields $(>88 \%)$ were obtained in comparatively less time $(2-6.5 \mathrm{~h})$. All the products were characterized by comparing melting points with those of the reported compounds. The reaction conditions such as temperature, time and amount of catalyst were optimized. The effect

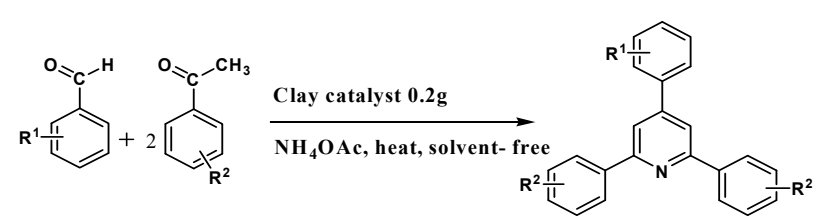

Scheme 1. K10 catalyzed one pot synthesis of triaryl pyridines.

Table 1. Results of recycling studies.

\begin{tabular}{cc}
\hline No. of recycling steps & $\%$ Yield \\
\hline 1 & 97 \\
2 & 92 \\
3 & 88 \\
\hline
\end{tabular}

Reaction condition: benzaldehyde (1 mmol), acetophenone $(2 \mathrm{mmol})$, $\mathrm{NH}_{4} \mathrm{OAc}(1.3 \mathrm{~mol} \%), 0.2$ gm catalyst reaction time $4 \mathrm{~h}$. Isolated yield.

of catalyst loading was studied by increasing the catalyst concentration from $0.05 \mathrm{~g}$ to $0.3 \mathrm{~g}$ with an increment of $0.05 \mathrm{~g}$ selecting benzaldehyde and acetophenone as substrates for $3 \mathrm{~h}$, the formation of product was found to increase up to $0.2 \mathrm{~g}$ further increase did not appreciably affect the yield of the product, optimum catalyst concentration of $0.2 \mathrm{~g}$ was selected for further studies, similarly temperature was also optimized by varying the temperature from $40^{\circ} \mathrm{C}-130^{\circ} \mathrm{C}$, optimum temperature obtained was $120^{\circ} \mathrm{C}$.

\section{Spectral Data of Selected Products}

2,4,6-triphenylpyridine (Entry 1, Table 2). Mp $130^{\circ} \mathrm{C}$ $132^{\circ} \mathrm{C}$; ${ }^{1} \mathrm{H}$ NMR $\left(\mathrm{CDCl}_{3}, 400 \mathrm{MHZ}\right): \delta 7.2-8.2(\mathrm{~m}, 17 \mathrm{H})$, LC-MS (m/z): $308.1(\mathrm{M}+1)$. FT-IR (KBr): 3032, 1604, $1544,1232,1025 \mathrm{~cm}^{-1}$.

4-phenyl-2,6-dip-tolylpyridine (Entry 2, Table 2) Mp $156^{\circ} \mathrm{C}-158^{\circ} \mathrm{C}{ }^{1} \mathrm{H} \mathrm{NMR}\left(\mathrm{CDCl}_{3}, 400 \mathrm{MHZ}\right): \delta 7.2-8.2$ $(\mathrm{m}, 15 \mathrm{H}), 2.4(\mathrm{~s}, 6 \mathrm{H})$, LC-MS $(\mathrm{m} / \mathrm{z}): 336.2(\mathrm{M}+1)$. FT-IR (KBr): 3030, 1654, 1593, 1330, $1180 \mathrm{~cm}^{-1}$.

4-(2,6-diphenylpyridin-4-yl) phenol (Entry 4, Table 2). Mp $197^{\circ} \mathrm{C} ;{ }^{1} \mathrm{H}$ NMR $\left(\mathrm{CDCl}_{3}, 400 \mathrm{MHZ}\right): \delta 8.2$ (dd, $4 \mathrm{H}, \mathrm{J}$ $=1.2 \mathrm{HZ}), 7.8(\mathrm{~s}, 2 \mathrm{H}), 7.68(\mathrm{~d}, 2 \mathrm{H}, \mathrm{J}=4.4 \mathrm{HZ}), 7.4-7.6$ (m, 6H), $7(\mathrm{~d}, 2 \mathrm{H}, \mathrm{J}=8.4 \mathrm{HZ}), 5(\mathrm{~s}, 1 \mathrm{H})$ LC-MS (m/z): $324.3(\mathrm{M}+1)$. FT-IR (KBr): 3038, 1598, 1517, 1602, $1207,1109 \mathrm{~cm}^{-1}$.

4-(4-nitrophenyl)-2,6-diphenylpyridine (Entry 5, Table 2). $\mathrm{Mp} 203^{\circ} \mathrm{C}-205^{\circ} \mathrm{C} ;{ }^{1} \mathrm{H}$ NMR $\left(\mathrm{CDCl}_{3}, 400 \mathrm{MHZ}\right)$ : $\delta 7.42$ - $7.89(\mathrm{~m}, 17 \mathrm{H})$, LC-MS (m/z): $353.3(\mathrm{M}+1)$. FT-IR (KBr): $3069,1608,1528,1351,1218 \mathrm{~cm}^{-1}$.

4-(4-chlorophenyl)-2,6-diphenylpyridine (Entry 7, Table 2). $\mathrm{Mp} 118^{\circ} \mathrm{C}-119^{\circ} \mathrm{C} ;{ }^{1} \mathrm{H}$ NMR $\left(\mathrm{CDCl}_{3}, 400 \mathrm{MHZ}\right)$ : $\delta 7.4-8.2(\mathrm{~m}, 16 \mathrm{H}) \mathrm{LC}-\mathrm{MS}(\mathrm{m} / \mathrm{z}): 342.8(\mathrm{M}+1)$. FT-IR (KBr): 3023, 1656, 1600, 1334, $1222 \mathrm{~cm}^{-1}$.

The effect of various ammonia sources was studied. Effect of the different ammonia derivatives on yield of the product were checked, maximum, yield was obtained for 
$\mathrm{NH}_{4} \mathrm{OAc}$. Results are summarized in Table 3.

The mechanism of triaryl pyridine synthesis is as shown in Scheme 2 [25]. First step involves the conden-

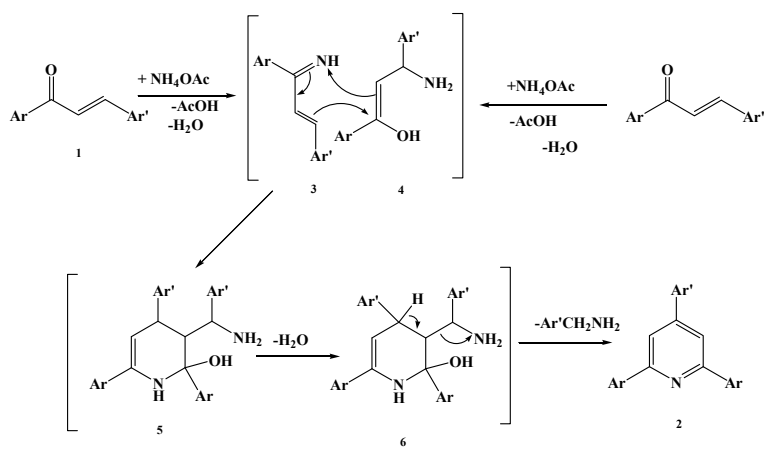

Scheme 2. Mechanism of formation of triaryl pyridines.

Table 2. Montmorillonite K10 clay catalyzed synthesis of triaryl pyridines ${ }^{\mathrm{a}}$.

\begin{tabular}{|c|c|c|c|c|c|}
\hline Entry & $\mathrm{R}_{1}$ & $\mathrm{R}_{2}$ & Time (h) & Yield $(\%)^{\mathrm{b}}$ & M.p $\left({ }^{\circ} \mathrm{C}\right)$ (lit.) \\
\hline 1 & $\mathrm{H}$ & $\mathrm{H}$ & 4 & 97 & $133-136(135)^{[23]}$ \\
\hline 2 & $\mathrm{H}$ & 4- $\mathrm{CH}_{3}$ & 6 & 93 & $156-158(157-158)^{[25]}$ \\
\hline 3 & $\mathrm{H}$ & $4-\mathrm{Br}$ & 5 & 92 & $194-196(192-194)^{[26]}$ \\
\hline 4 & $4-\mathrm{OH}$ & $\mathrm{H}$ & 5 & 97 & $197-198(197-198)^{[23]}$ \\
\hline 5 & $4-\mathrm{NO}_{2}$ & $\mathrm{H}$ & 6 & 91 & $203-205(202-203)^{[23]}$ \\
\hline 6 & $2-\mathrm{Cl}$ & $\mathrm{H}$ & 4.5 & 93 & $113-114(109-111)^{[26]}$ \\
\hline 7 & $4-\mathrm{Cl}$ & $\mathrm{H}$ & 4 & 94 & $126-127(129-130)^{[23]}$ \\
\hline 8 & $4-\mathrm{OCH}_{3}$ & $\mathrm{H}$ & 7 & 96 & $101-102(98)^{[25]}$ \\
\hline 9 & $4-\mathrm{CH}_{3}$ & $\mathrm{H}$ & 6.5 & 95 & $116-118(116)^{[24]}$ \\
\hline 10 & $4-\mathrm{CH}_{3}$ & $4-\mathrm{CH}_{3}$ & 5 & 90 & $177-178(178-180)^{[26]}$ \\
\hline 11 & $3-\mathrm{NO}_{2}$ & $4-\mathrm{Br}$ & 5 & 89 & $>200$ \\
\hline 12 & $4-\mathrm{Cl}$ & 4- $\mathrm{CH}_{3}$ & 4 & 96 & $199-201(200-202)^{[25]}$ \\
\hline 13 & $4-\mathrm{Cl}$ & $4-\mathrm{Br}$ & 5 & 94 & $>200$ \\
\hline 14 & Thio & $\mathrm{H}$ & 4 & 91 & $168-170(68-170)^{[25]}$ \\
\hline 15 & Thio & $4-\mathrm{CH}_{3}$ & 3.5 & 88 & $162-163(164-165)^{[25]}$ \\
\hline
\end{tabular}

${ }^{a}$ Reaction conditions: Temperature $120^{\circ} \mathrm{C}$, Catalyst 0.2 g, aldehyde: $\mathrm{NH}_{4} \mathrm{OAc}$ : ketone:1:1.3:2 mmol. ${ }^{\mathrm{b}}$ Isolated yield of product.

Table 3. Effect of various ammonia sources on the yield of product $^{\mathrm{a}}$.

\begin{tabular}{ccc}
\hline Ammonia source & Time (h) & Yield \% \\
\hline $\mathrm{NH}_{4} \mathrm{OAc}$ & 4 & 97 \\
$\mathrm{NH}_{2} \mathrm{CONH}_{2}$ & 6 & 40 \\
$\mathrm{NH}_{2} \mathrm{COCH}_{3}$ & 5 & 65 \\
$\mathrm{NH}_{2} \mathrm{CSNH}_{2}$ & 4.5 & 36 \\
\hline
\end{tabular}

${ }^{\mathrm{a}}$ Reaction conditions: Temperature $120^{\circ} \mathrm{C}$, Catalyst 0.2 g, aldehyde: $\mathrm{NH}_{4} \mathrm{OAc}$ : ketone:1:1.3:2 mmol. ${ }^{\mathrm{b}}$ Isolated yield of product. sation of ammonia with a molecule of chalcone and Michel addition of ammonia to the second molecule of chalcone leads to the formation of 2,4-diaryl-1-azadiene 3 and the $1: 1$ adduct 4 probably undergoes a formal [ $4+2]$ cycloaddition to form tetrahydro pyridine intermediate 5 . Dehydration to dihydropyridine intermediate 6 and then oxidative aromatization with removal of the benzyl side chain would yield 2,4,6-triarylpyridine. According the mechanism, the role of $\mathrm{NH}_{4} \mathrm{OAc}$ is as nitrogen source and acetic acid is formed as by-product, the reaction is catalysed by acid, the presence of acetic acid increases the acidity of the medium.

The main advantages of the present method in the synthesis of triarylpyridines are that they are clean reactions without any side product under solvent free condition and workup does not require column chromatography. The catalyst could be recycled efficiently for three cycles without any appreciable loss in the yield.

\section{Conclusion}

A mild, efficient and environmentally friendly approach for the synthesis of 2,4,6-trisubstituted pyridines via cyclo condensation of aromatic ketones with aromatic aldehydes and ammonium acetate in the presence of Montmorillonite K10 clay as a recyclable solid acid catalyst has been developed. The trisubstituted pyridines were produced with $100 \%$ selectivity without formation of any other side product. The green context of the reaction is the use of non corrosive catalyst under solvent free reaction condition and workup procedure does not require column chromatography.

\section{Acknowledgements}

One of the authors VK is thankful to UGC for teacher fellowship and SAIF Cochin for ${ }^{1} \mathrm{H}$ NMR analysis.

\section{REFERENCES}

[1] A. U. Lesanko and D. G. Hall, "Wanted: New Multicomponent Reactions for Generating Libraries of Polycyclic Natural Products," Current Opinion in Chemical Biology, Vol. 9, No. 3, 2005, pp. 266-276. doi:10.1016/j.cbpa.2005.04.003

[2] N. Li, P. Wang, S. L. Lai, W. Liu, C. S. Lee, S. T. Lee and Z. Liu, "Synthesis of Multiaryl-Substituted Pyridine Derivatives and Applications in Non-Doped Deep-Blue OLEDs as Electron-Transporting Layer with High HoleBlocking Ability," Advanced Materials, Vol. 22, No. 4, 2010, pp. 527-530. doi:10.1002/adma.200902430

[3] L. C. W. Chang, J. K. Von Frijtag, D. Kunzel, T. M. Mulder-Kriegger, R. F. Spangersberg, S. F. Roerink, G. Hout, M. W. Beukers, J. Brussee and A. P. Ijzerman, "A Series of Ligands Displaying a Remarkable Agonistic-Antagonistic Profile at the Adenosine $A_{1}$ Receptor," Journal of 
Medicinal Chemistry, Vol. 48, No. 6, 2005, pp. 20452053. doi:10.1021/jm049597+

[4] M. W. Beukers, L. W. Chang, J. K. von Frijtag, D. Künzel, T. Mulder-Krieger, R. F. Spanjersberg, J. Brussee and A. P. I. Jzerman, "New, Non-Adenosine, High-Potency Agonists for the Human Adenosine $\mathrm{A}_{2 \mathrm{~B}}$ Receptor with an Improved Selectivity Profile Compared to the Reference Agonist $\mathrm{N}$-Ethylcarboxamidoadenosine," Journal of $\mathrm{Me}$ dicinal Chemistry, Vol. 47, No. 15, 2004, pp. 3707-3709. doi:10.1021/jm049947s

[5] A. D. Pillai, P. D. Rathod, P. X. F. M. Patel, M. Nivsarkar, K. K. Vasu, H. Padh and V. Sudarsanam, "Novel Drug Designing Approach for Dual Inhibitors as Anti-Inflammatory Agents: Implication of Pyridine Template," Biochemical and Biophys Research Communications, Vol. 301, No. 1, 2003, pp. 183-186. doi:10.1016/S0006-291X(02)02996-0

[6] G. W. Cave, M. J. Hardie, B. A. Roberts and C. L. Raston, "A Versatile Six-Component Molecular Capsule Based on Benign Synthons-Selective Confinement of a Heterogeneous Molecular Aggregate," European Journal of Organic Chemistry, Vol. 2001, No. 17, 2001, pp. 32273231.

doi:10.1002/1099-0690(200109)2001:17<3227::AID-EJO C3227>3.0.CO;2-V

[7] R. R. Jetti, A. Nagia, F. Xue and T. C. W. Mak, "Polar HostGuest Assembly Mediated by Halogen... $\pi$ Interaction: Inclusion Complexes of 2,4,6-Tris (4-halophenoxy)-1,3,5triazine $($ Halo $=$ Chloro, Bromo) with Trihalobenzene $($ Halo = Bromo, Iodo)," Chemical Communications, No. 10, 2001, pp. 919-920. doi:10.1039/b102150h

[8] Z. C. Watson, N. Bampos and J. M. Sanders, "Mixed Cyclic Trimers of Porphyrins and Dioxoporphyrins: Geometry vs. Electronics in Ligand Recognition," New Journal of Chemistry, Vol. 22, No. 11, 1998, pp. 1135-1138. doi:10.1039/a805504a

[9] F. Chubb, A. S. Hay and R. B. Sandin, "The Leuckart Reaction of Some 1,5-Diketones," Journal of American Chemical Society, Vol. 75, No. 23, 1953, pp. 6042-6044. doi:10.1021/ja01119a508

[10] R. S. Tewari and A. K. Dubey, "Studies on Cycloimmonium Ylides. Synthesis of Some 2,4,6-Triaryl-Substituted Pyridines via Isoquniolinium Ylides," Journal of Chemical Engineering Data, Vol. 25, No. 1, 1980, pp. 91-92. doi:10.1021/je60084a032

[11] S. P. Kendurkar and R. S. Tewari, "Synthesis of Some New 2,4,6-Triaryl-Substituted Pyridines Via Aroylmethylenepyridinium Ylides," Journal of Chemical Engineering Data, Vol. 19, No. 2, 1974, pp. 184-188. doi:10.1021/je60061a004

[12] F. Kröhnke, W. Zecher, J. Curtze, D. Drechsler, K. Pfleghar, K. E. Schnalke and W. Weis, "Syntheses Using the Michael Adddition of Pyridinium Salts," Angewandte Chemie International Edition in English, Vol. 1, No. 12, 1962, pp. 626-632. doi:10.1002/anie.196206261

[13] K. T. Potts, M. J. Cipullo, P. Ralli and G. Theodoridis, "Ketenedithioacetals as Synthetic Intermediates. A Versatile Synthesis of Pyridenes, Polypyridinyls, and Pyrylium
Salts," Journal of American Chemical Society, Vol. 103, No. 12, 1981, pp. 3584-3585.

http://dx.doi.org/10.1021/ja00402a062

[14] T. Kobayashi, H. Kakiuchi and H. Kato, "On the Reaction of $\mathrm{N}$-(Diphenylphosphinyl)-1-phenylethanimine with Aromatic Aldehydes Giving 4-Aryl-2,6-diphenylpyridine Derivatives," Bulletin of the Chemical Society of Japan, Vol. 64, No. 2, 1991, pp. 392-395. doi:10.1246/bcsj.64.392

[15] F. Palacios, A. O. Retana and J. A. Oyarzabal, "A 'One Pot' Synthesis of Polysubstituted Pyridines from Metallated Alkylphosphonates, Nitriles and $\alpha, \beta$-Unsaturated Ketones," Tetrahedron Letters, Vol. 37, No. 26, 1996, pp. 45774580. doi:10.1016/0040-4039(96)00850-7

[16] G. W. V. Cave and C. L. Raston, “Towards Benign SynThesis of Pyridines Involving Sequential Solvent Free Aldol and Michael Addition Reactions," Chemical Communications, No. 22, 2000, pp. 2199-2200. doi: $10.1039 / \mathrm{b} 0074310$

[17] S. Tu, T. Li, F. Shi, F. Fang, S. Zhu, X. Wei and Z. Zong, "An Efficient Improve for the Kröhnke Reaction: OnePot Synthesis of 2,4,6-Triarylpyridines Using Raw Materials under Microwave Irradiation," Chemistry Letters, Vol. 34, No. 5, 2005, pp. 732-733. doi:10.1246/cl.2005.732

[18] K. Motokura, S. Matsunaga, A. Miyaji, Y. Sakamoto and T. Baba, "Heterogeneous Allylsilation of Aromatic and Aliphatic Alkenes Catalyzed by Proton-Exchanged Montmorillonite," Organic Letters, Vol. 12, No. 7, 2010, pp. 15081511. doi:10.1021/ol100228t

[19] K. Motokura, M. Tada and Y. Iwasawa, "Layered Materials with Coexisting Acidic and Basic Sites for Catalytic One-Pot Reaction Sequences," Journal of American Chemical Society, Vol. 131, No. 23, 2009, pp. 7944-7945. doi:10.1021/ja9012003

[20] M. Nose, T. Mizugaki, K. Jitsukawa and K. Kaneda, "Reusable Montmorillonite-Entrapped Organocatalyst for Asymmetric Diels-Alder Reaction," Tetrahedron Letters, Vol. 49, No. 38, 2008, pp. 5464-5466. doi:10.1016/j.tetlet.2008.07.011

[21] S. B. Neji, M. Trabelsi and M. H. Frikha, "Esterification of Fatty Acids with Short-Chain Alcohols over Commercial Acid Clays in a Semi-Continuous Reactor," Energies, Vol. 2, No. 4, 2009, pp. 1107-1117. doi:10.3390/en20401107

[22] M. R. Dintzner, Y. A. Mondjnou and D. J. Pileggi, "Montmorillonite Clay-Catalyzed Cyclotrimerization and Oxidation of Aliphatic Aldehydes," Tetrahedron Letters, Vol. 51, No. 5, 2010, pp. 826-827. doi:10.1016/j.tetlet.2009.12.009

[23] T. Kobayashi, H. Kakiuchi and H. Kato, "On the Reaction of $\mathrm{N}$-(Diphenylphosphinyl)-1-phenylethanimine with Aromatic Aldehydes Giving 4-Aryl-2,6-diphenylpyridine Derivatives," Bulletin of the Chemical Society of Japan, Vol. 64, No. 2, 1991, pp. 392-395. doi:10.1246/bcsj.64.392

[24] P. G. Ingole, S. V. Jadhav and H. C. Bajaj, "Ionic Liquid Mediated One Pot Synthesis of Substituted 2,4,6-Triarylpyridines," International Journal of Chemical Technological Research, Vol. 2, No. 1, 2010, pp. 289-294. 
[25] M. Adib, H. Tahermansouri, S. A. Koloogani, B. Mohammadi and H. R. Bijanzadeh, "Krohnke Pyridines: An Efficient Solvent Free Synthesis of 2,4,6-triarylpyridines," Tetrahedron Letters, Vol. 47, No. 33, 2006, pp. 59575960. doi:10.1016/i.tetlet.2006.01.162
[26] X. Q. Huang, H. X. Li, J. X. Wang and X. F. Jia, "A Rapid and Efficient Synthesis of 2,4,6-Triarylpyridines under Microwave Irradiation," Chinese Chemical Letters, Vol. 16, No. 5, 2005, pp. 607-608. 